\title{
Triterpene Glycosides from Polygala klotzschii
}

\author{
Hans Ch. Krebs*, Petra Sollinger \\ Chemisches Institut, Tierärztliche Hochschule, \\ Bischofsholer Damm 15, D-30173 Hannover, Germany
}

Z. Naturforsch. 51 b, 897-900 (1996); received November 10, 1995

Polygala klotzschii, Polygalaceae, Triterpene Glycosides, Medicagenic Acid,

16 $\alpha$-Hydroxy-medicagenic Acid

Polygala klotzschii is a toxic plant growing in Brazil. From the methanolic extract of its leaves, two triterpene glycosides could be isolated. Their structures have been determined by spectroscopic means as well as through degradation reactions and by preparing the alditolacetates. The glycosides were identified as 28-O-[ $\beta$-D-glucofuranosyl(1-2)- $\beta$-D-xylopyranosyl(1-4)- $\alpha$-Lrhamnopyranosyl( $1-4)$-[ $\alpha$-D-xylopyranosyl( $1-3)]-\beta$-D-xylopyranosyl]-3-O- $\beta$-D-glucopyranosyl-medicagenate (1) and 28-O-[ $\alpha$-L-rhamnopyranosyl (1-4)- $\alpha$-L-rhamnopyranosyl (1-4)- $[\beta$-Dxylofuranosyl(1-2)- $\beta$-D-xylopyranosyl(1-3)]- $\beta$-D-xylopyranosyl]-3-O- $\beta$-D-glucopyranosyl$16 \alpha$-hydroxymedicagenate $(2)$ respectively.

\section{Introduction}

Polygala klotzschii (Polygalaceae), a small and thorny shrub, is well-known in Brazil as Laranjinha and Limaozinho. It is among the most important poisonous plants in the states of Sao Paulo and Mato Grosso do Sul. The symptoms of poisoning were investigated by Tokarnia et al. for cattle [1]. They occur rather early with nervous disturbances: the animals fall down and show irregular movements of the head and have accelerated, irregular respiration. Two to three hours after the intake of the plant, acute diarrhoea sets in, which is followed by death within a short time. The lethality is $10 \mathrm{~g}$ of leaves per $\mathrm{kg}$ body weight of the animal.

5-Methoxypodophyllotoxin has been isolated from the leaves of P. klotzschii [2, 3]. Our further investigations led to the isolation of triterpene glycosides which are described in the present paper.

\section{Results and Discussion}

The methanol extract of the dried and powdered leaves of $P$. klotzschii has been partitioned between water and chloroform. Further partitioning of the water layer between water and $n$-butanol followed by several chromatographic separations of the butanolic phase led to the isolation of two new triterpene glycosides $\mathbf{1}$ and $\mathbf{2}$.

\footnotetext{
* Reprint requests to Priv.-Doz. Dr. H. Ch. Krebs.
}
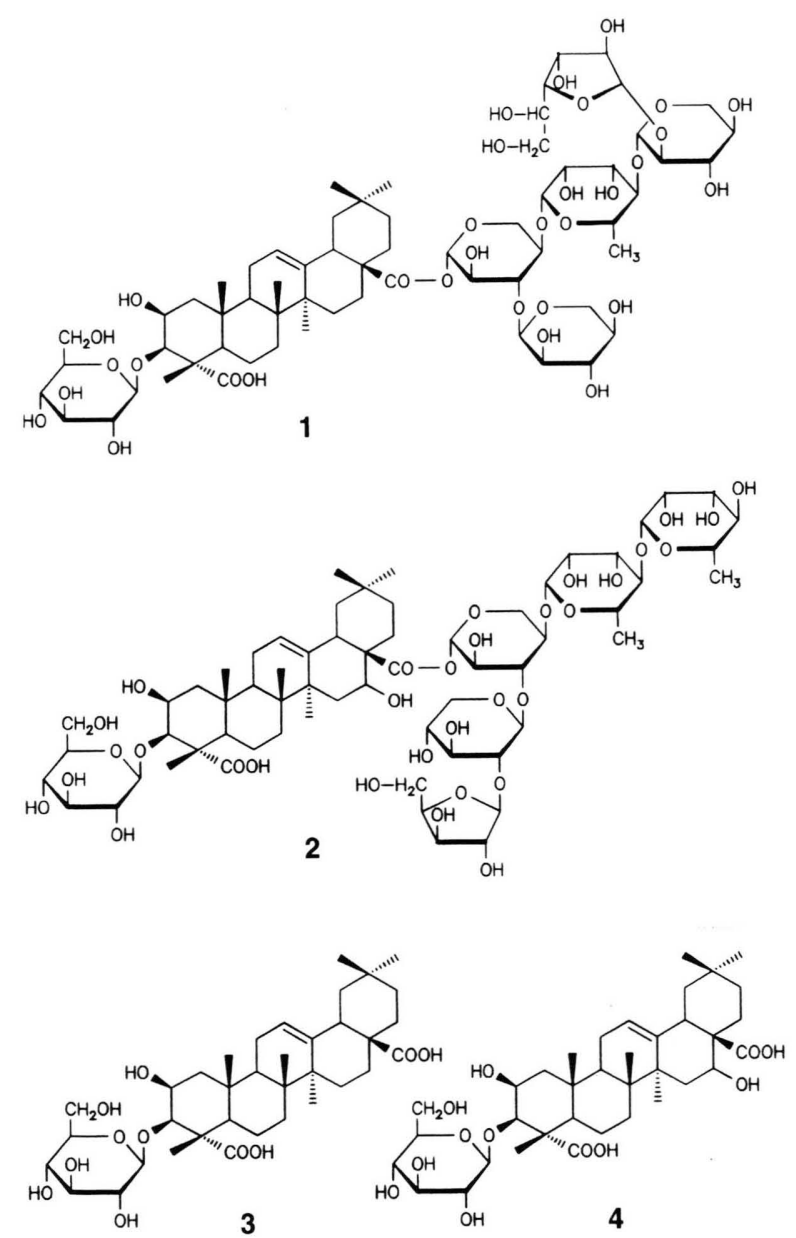

Scheme 1. Structures of the glycosides $\mathbf{1}$ and $\mathbf{2}$ and Prosapogenins $\mathbf{3}$ and $\mathbf{4}$. 
Table I. ${ }^{13} \mathrm{C}$ NMR data of $\mathbf{1}$ (in $\left.\mathrm{CD}_{3} \mathrm{OD}\right), 2\left(\mathrm{CD}_{3} \mathrm{OD}\right.$ ), 3 (pyridine- $\mathrm{D}_{5}$ ), $\mathbf{4}$ (pyridine- $\mathrm{D}_{5}$ ) and 28-O-[ $\beta$-D-xylopyranosyl-(1-4)- $\alpha$-L-rhamnopyranosyl-(1-2)- $\alpha$-L-arabinopyranosyl]-3-O- $\beta$-D-glucopyranosyl-medicagenate [4]; aglycone part.

\begin{tabular}{rrrrrr}
\hline C- & \multicolumn{1}{c}{$\mathbf{1}$} & \multicolumn{1}{c}{$\mathbf{2}$} & \multicolumn{1}{c}{$\mathbf{3}$} & \multicolumn{1}{c}{$\mathbf{4}$} & Ref. [4] \\
\hline 1 & 44.6 & 44.8 & 44.3 & 44.5 & 43.5 \\
2 & 71.0 & 70.1 & 71.6 & 70.5 & 69.8 \\
3 & 86.5 & 86.1 & 86.2 & 86.5 & 86.0 \\
4 & 51.3 & 53.1 & 53.0 & 52.6 & 52.6 \\
5 & 53.0 & 50.3 & 52.5 & 49.7 & 52.5 \\
6 & 21.7 & 21.7 & 21.6 & 21.4 & 20.6 \\
7 & 33.7 & 31.8 & 33.2 & 31.1 & 32.8 \\
8 & 42.6 & 41.2 & 40.3 & 41.7 & 40.1 \\
9 & 49.8 & 49.0 & 48.8 & 48.1 & 48.5 \\
10 & 37.2 & 37.3 & 36.9 & 37.1 & 36.4 \\
11 & 23.5 & 24.6 & 23.8 & 24.2 & 23.4 \\
12 & 123.7 & 123.6 & 122.6 & 123.5 & 122.5 \\
13 & 144.7 & 144.7 & 145.0 & 145.0 & 143.5 \\
14 & 43.1 & 40.1 & 42.4 & 40.7 & 42.3 \\
15 & 29.3 & 36.2 & 28.3 & 36.3 & 27.8 \\
16 & 24.6 & 74.9 & 24.1 & 74.9 & 23.8 \\
17 & 49.9 & 47.6 & 46.7 & 47.4 & 47.2 \\
18 & 40.9 & 42.1 & 42.1 & 42.5 & 41.5 \\
19 & 44.6 & 48.6 & 46.6 & 48.1 & 46.4 \\
20 & 31.5 & 27.4 & 31.0 & 27.5 & 31.0 \\
21 & 34.8 & 30.1 & 34.3 & 30.0 & 34.2 \\
22 & 33.1 & 36.3 & 33.3 & 36.4 & 32.5 \\
23 & 182.8 & 183.0 & 181.3 & 181.1 & 180.5 \\
24 & 14.2 & 13.9 & 14.4 & 14.0 & 13.2 \\
25 & 17.2 & 17.3 & 16.9 & 17.1 & 16.4 \\
26 & 18.0 & 18.1 & 17.5 & 17.6 & 17.0 \\
27 & 26.3 & 25.2 & 26.4 & 25.2 & 26.0 \\
28 & 178.1 & 177.0 & 180.3 & 180.0 & 175.8 \\
29 & 33.5 & 33.4 & 33.4 & 33.4 & 33.1 \\
30 & 23.4 & 24.9 & 23.9 & 24.2 & 23.9 \\
\hline & & & & &
\end{tabular}

The IR spectra of $\mathbf{1}$ and $\mathbf{2}$ are rather similar and show strong $\mathrm{OH}$ absorption at about $\nu_{\max } 3410$ $\mathrm{cm}^{-1}$ thus suggesting that both compounds are glycosides. After acid hydrolysis of $\mathbf{1}$ and $\mathbf{2}$ the aglycones were easily identified as medicagenic acid and $16 \alpha$-hydroxy-medicagenic acid respectively, by comparison of their NMR spectra with literature data $[4,5]$. In addition, the hydrolysis afforded glucose, rhamnose and xylose in each case, as determined by GC (persilylated) comparison with the authentic monosaccharides.

Alkaline hydrolysis of $\mathbf{1}$ and $\mathbf{2}$ gave the prosapogenins 3 and $\mathbf{4}$, both containing a glucose residue, concluded from the NMR data and from GC analysis after acid hydrolysis of $\mathbf{3}$ and $\mathbf{4}$.

Structural determination of the both saponins were based on NMR spectral assignment, FAB- mass spectroscopy and on GC-MS analysis of the alditol acetates derived from $\mathbf{1}$ and $\mathbf{2}$. The ${ }^{1} \mathrm{H}$ NMR spectrum of $\mathbf{1}$ shows 6 signals for anomeric protons between 4.3 and $5.5 \mathrm{ppm}$. The ${ }^{13} \mathrm{C}$ NMR data (see Tables I and II) confimed the existance of 6 monosaccharide residues by peaks at 106.3 (C-1 glucose), 104.8 (glucose), 104.3 (xylose), 102.9 (rhamnose), 100.9 (xylose) and 94.5 (xylose). The latter value is typically for the C-1 of a sugar attached to a carboxylic group. The signals derived from the aglycone part, medicagenic acid, are in good agreement with $28-\mathrm{O}-[\beta$-D-xylopyranosyl-(1-4)- $\alpha$ L-rhamnopyranosyl-(1-2)- $\alpha$-L-arabinopyranosyl]3-O- $\beta$-D-glucopyranosyl-medicagenate described by Massiot et al. [4] (see Table I).

The FAB mass spectrum of glycoside 1 shows a $\left[\mathrm{M}-\mathrm{H}^{+}\right]$peak at $\mathrm{m} / z 1367$ as well as further signals for degradation products, resulted from loss of monosaccharide units: $\mathrm{m} / \mathrm{z} 1205$ (M - glucose), 1073 (M - glucose - xylose), 663 (M - glucose $3 \times$ xylose - rhamnose) and $501(\mathrm{M}-2 \times$ glucose $-3 \times$ xylose - rhamnose). The monosaccharide residues could be assigned because of their different molecular weight. The fragment $\mathrm{m} / \mathrm{z}, 663$ resulted from simultaneous loss of three monosaccharide units from $\mathrm{m} / \mathrm{z} 1073$ that points to a branching in the sugar chain [6]. Partially methylated alditol acetates were prepared from 1 followed by GC-MS analysis [7, 8]. Six compounds could be identified: 1,5-Di-O-acetyl-2,3,4-tri-O-methylpentitol,

1,4,5-tri-O-acetyl-6-deoxy-2,3-di-O-methylhexitol, 1,2,5-tri-O-acetyl-3,4-di-O-methylpentitol,

1,5-di-O-acetyl-2,3,4,6-tetra-O-methylhexitol, 1,4-di-O-acetyl-2,3,5,6-tetra-O-methylhexitol and 1,3,4,5-tetra-O-acetyl-2-O-methylpentitol.

These results indicated three terminal sugar residues, two glucose and a xylose unit. Another xylose residue is the branching point in the sugar chain; it is substituted in position 1 (with the carboxylic function C-28 of the aglycone), 3 and 4 . To distinguish which sugar moiety is attached at C-3 and which at C-4 of this inner xylose unit, the ${ }^{13} \mathrm{C}$ NMR values were compared with literature data [9] for suitable saccharides. The final structure has been determined by ${ }^{13} \mathrm{C}$ NMR data (Tables I and II) as 28-O-[ $\beta$-D-glucofuranosyl(1-2)- $\beta$-Dxylopyranosyl(1-4)- $\alpha$-L-rhamnopyranosyl(1-4)-

[ $\alpha$-D-xylopyranosyl(1-3)]- $\beta$-D-xylopyranosyl]-3O- $\beta$-D-glucopyranosyl-medicagenate (1). 
Table II. ${ }^{13} \mathrm{C}$ NMR data of $\mathbf{1}$ (in $\left.\mathrm{CD}_{3} \mathrm{OD}\right), \mathbf{2}\left(\mathrm{CD}_{3} \mathrm{OD}\right)$, 3 (pyridine- $\mathrm{D}_{5}$ ), and $\mathbf{4}$ (pyridine- $\mathrm{D}_{5}$ ); sugar residues.

\begin{tabular}{|c|c|c|c|c|}
\hline C- & 1 & 2 & 3 & 4 \\
\hline & glu & glu & glu & glu \\
\hline 1 & 104.8 & 104.8 & 105.3 & 105.2 \\
\hline 2 & 73.9 & 74.8 & 75.3 & 75.4 \\
\hline 3 & 76.8 & 77.9 & 78.4 & 78.3 \\
\hline 4 & 71.0 & 70.9 & 70.4 & 71.8 \\
\hline 5 & 76.8 & 77.9 & 78.4 & 78.3 \\
\hline 6 & 62.1 & 62.8 & 62.7 & 62.9 \\
\hline $\begin{array}{l}1 \\
2 \\
3 \\
4 \\
5\end{array}$ & $\begin{array}{l}\text { xyl } \\
94.5 \\
72.3 \\
84.6 \\
75.0 \\
67.1\end{array}$ & & $\begin{array}{l}\text { xyl } \\
93.7 \\
75.5 \\
71.8 \\
78.2 \\
64.5\end{array}$ & \\
\hline 5 & rha & & rha & \\
\hline 1 & 102.9 & & 105.0 & \\
\hline 2 & 71.0 & & 70.9 & \\
\hline 3 & 71.7 & & 71.4 & \\
\hline 4 & 83.3 & & 80.1 & \\
\hline 5 & 68.6 & & 66.2 & \\
\hline \multirow[t]{2}{*}{6} & 18.0 & & 23.9 & \\
\hline & xyl & & rha & \\
\hline 1 & 104.3 & & 101.2 & \\
\hline 2 & 84.6 & & 71.1 & \\
\hline 3 & 77.4 & & 71.9 & \\
\hline 4 & 70.4 & & 74.7 & \\
\hline 5 & 66.3 & & 69.4 & \\
\hline \multirow[t]{2}{*}{6} & & & 17.9 & \\
\hline & glu & & xyl & \\
\hline 1 & 106.3 & & 110.9 & \\
\hline 2 & 77.4 & & 78.2 & \\
\hline 3 & 76.2 & & 74.9 & \\
\hline 4 & 83.2 & & 69.4 & \\
\hline 5 & 71.7 & & 65.0 & \\
\hline \multirow[t]{2}{*}{6} & 65.5 & & & \\
\hline & xyl & & xyl & \\
\hline 1 & 100.9 & & 112.0 & \\
\hline 2 & 72.3 & & 81.3 & \\
\hline 3 & 74.4 & & 75.9 & \\
\hline 4 & 70.1 & & 81.7 & \\
\hline 5 & 62.4 & & 63.1 & \\
\hline
\end{tabular}

The ${ }^{1} \mathrm{H}$ NMR spectrum of glycoside 2 also shows six signals for anomeric protons $(\delta 4.35-5.75 \mathrm{ppm})$ and the ${ }^{13} \mathrm{C}$ NMR data confirm this result (Tables I and II). Again, one sugar is attached to a carboxylic group having a resonance at $\delta 93.7 \mathrm{ppm}$ for $\mathrm{C}-1$. The FAB mass spectrum revealed with a peak at $m / z 1367$ for $\left[\mathrm{M}-\mathrm{H}^{+}\right]$the same molecular formula, $\mathrm{C}_{63} \mathrm{H}_{100} \mathrm{O}_{32}$, as compound $\mathbf{1}$. The loss of sugar residues led to the following peaks: $\mathrm{m} / \mathrm{z}, 1221$ (M - rhamnose), 1089 (M - rhamnose - xylose), 679
(M $-2 \times$ rhamnose $-3 \times$ xylose $)$ and $517(\mathrm{M}-$ $2 \times$ rhamnose $-3 \times$ xylose - glucose $)$. From the latter peak, the molecular weight of the aglycone can be calculated 518, thus containing one oxygen more than medicagenic acid. The aglycone could be identified by mass spectroscopy after acid hydrolysis of $\mathbf{2}$ as $16 \alpha$-hydroxy-medicagenic acid. The sugar chain in $\mathbf{2}$ must also be branched, indicated by the simultaneous loss of three monosaccharide units $(\mathrm{m} / \mathrm{z}, 1089$ to $\mathrm{m} / \mathrm{z} 679)$.

In order to determine the connectivity of the sugar residues, partially methylated alditol acetates were prepared. The following compounds were identified by GC-MS analysis:

1,4-Di-O-acetyl-2,3,5-tri-O-methylpentitol, 1,4,5-tri-O-acetyl-6-deoxy-2,3-di-O-methylhexitol, 1,2,5-tri-O-acetyl-3,4-di-O-methylpentitol,

1,5-di-O-acetyl-2,3,4,6-tetra-O-methylhexitol, 1,3,4,5-tetra-O-acetyl-2-O-methylpentitol and 1,5-di-O-acetyl-6-deoxy -2,3,4-tri-O-methylhexitol. Again, three terminal sugars were found, rhamnose, xylose and glucose, and a xylose unit is the branching point, connected in positions 3 and 4 with further saccharides. The structure of $\mathbf{2}$ has been determined as 28-O-[ $\alpha$-L-rhamnopyranosyl(1-4)- $\alpha$-L-rhamnopyranosyl(1-4)-[ $\beta$-D-xylofuranosyl(1-2)- $\beta$-Dxylopyranosyl(1-3)]- $\beta$-D-xylopyranosyl]-3-O- $\beta$ D-glucopyranosyl-16 $\alpha$-hydroxy-medicagenate.

Again, the ${ }^{13} \mathrm{C}$ NMR data of the sugar residues were compared with those of methylaldosides [9 - 13].

The symptoms seems to be a combination of the toxic effects of the single substances. The resorption of 5-methoxy-podophyllotoxin is markedly enhenced by the saponins. The glycosides are toxic also in in vitro tests against F21 fibroblasts, FOS fibroblasts, Hela cells, T-lymphocytes and Blymphocytes.

\section{Experimental}

General. Leaves of Polygala klotzschii have been collected in november 1988 in the state Sao Paulo, Brazil. IR: KBr; ${ }^{1} \mathrm{H}$ NMR: $300 \mathrm{MHz}, \mathrm{CD}_{3} \mathrm{OD}$ or pyridine- $\mathrm{D}_{5}$, TMS as int. standard; ${ }^{13} \mathrm{C}$ NMR: $75 \mathrm{MHz}, \mathrm{CD}_{3} \mathrm{OD}$ or pyridine- $\mathrm{D}_{5}$, TMS as int. standard.

Extraction and isolation. 1,000 g dried and powdered leaves were extracted three times with $10 \mathrm{l}$ ethanol at room temp. for $20 \mathrm{~h}$, each. After filtration the solvent was evaporated. The resulted $168 \mathrm{~g}$ of extract were partitioned between water and chloroform. The water solution was freeze dried and extracted with n-butanol. After evapo- 
ration of the butanol phase the residue was disolved in methanol and precipitated with diethylether. The precipitate was filtered and separated by column chromatography using silica gel and Sephadex LH20. $11 \mathrm{mg} 1$ and $19 \mathrm{mg}$ 2 could be obtained.

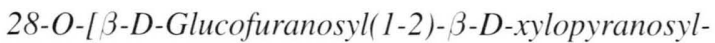
(1-4)- $\alpha$-L-rhamnopyranosyl( $1-4)$-[ $\alpha-D$-xylopyranosyl-

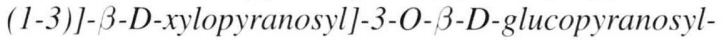
medicagenate (1)

M. p.: > $238^{\circ} \mathrm{C}$ (decomposition). $[\alpha]_{\mathrm{D}}^{20}+4.3(\mathrm{MeOH}$; $c$ 0.8540). IR (KBr) $\nu_{\max } \mathrm{cm}^{-1}: 3413(\mathrm{OH}), 2932(\mathrm{CH})$, $1715(\mathrm{C}=\mathrm{O}), 1074$. FAB-MS: $m / z$ (rel. int.): 1367 (55), 1205 (12), 1073 (3), 663 (25), 501 (10), 439 (100). ${ }^{1} \mathrm{H}$ NMR $\left(\mathrm{CD}_{3} \mathrm{OD}\right): \delta 5.48(1 \mathrm{H}, \mathrm{d}, J=5 \mathrm{~Hz}), 5.31(1 \mathrm{H}, \mathrm{m}$, H-12), 4.80 (1H, d, $J=6 \mathrm{~Hz}), 4.50(1 \mathrm{H}, \mathrm{d}, J=7 \mathrm{~Hz}), 4.40$ $(1 \mathrm{H}, \mathrm{d}, J=8 \mathrm{~Hz}), 4.37(1 \mathrm{H}, \mathrm{d}, J=7 \mathrm{~Hz}), 4.30(1 \mathrm{H}, \mathrm{d}, J=$ $2 \mathrm{~Hz}) \cdot{ }^{13} \mathrm{C}$ NMR $\left(\mathrm{CD}_{3} \mathrm{OD}\right)$ : see Tables I and II.

28-O-[ $\alpha$-L-Rhamnopyranosyl( $1-4)$ - $\alpha$-L-rhamnopyranosyl(1-4)-[ $\beta$-D-xylofuranosyl( $1-2)-\beta$-D-xylopyranosyl(1-3)]- $\beta$-D-xylopyranosyl]-3-O- $\beta$-D-glucopyranosyl$16 \alpha$-hydroxy-medicagenate (2)

M. p.: > $223^{\circ} \mathrm{C}$ (decomposition). $[\alpha]_{\mathrm{D}}^{20}+9.2(\mathrm{MeOH}$; c 0.9210). IR (KBr) $\nu_{\max } \mathrm{cm}^{-1}: 3408(\mathrm{OH}), 2931(\mathrm{CH})$, $1724(\mathrm{C}=\mathrm{O}), 1385,1278,1076,1044,1030$. FAB-MS $\mathrm{m} / \mathrm{z}$ (rel. int.): 1367 (8), 1221 (65), 1089 (10), 679 (15), 517 (5), 455 (50), 183 (100). ${ }^{1} \mathrm{H}$ NMR (CD $\left.{ }_{3} \mathrm{OD}\right): \delta 5.70$ $(1 \mathrm{H}, \mathrm{d}, J=3 \mathrm{~Hz}), 5.40(1 \mathrm{H}, \mathrm{d}, J=2 \mathrm{~Hz}), 5.29(1 \mathrm{H}, \mathrm{m}$, $\mathrm{H}-12), 4.65$ (1H, d, $J=8 \mathrm{~Hz}), 4.50(1 \mathrm{H}, \mathrm{d}, J=2 \mathrm{~Hz})$,
$4.40(1 \mathrm{H}, \mathrm{d}, J=6 \mathrm{~Hz}), 4.35(1 \mathrm{H}, \mathrm{d}, J=8 \mathrm{~Hz}) \cdot{ }^{13} \mathrm{C} \mathrm{NMR}$ $\left(\mathrm{CD}_{3} \mathrm{OD}\right)$ : see Tables I and II.

\section{3-O-3-D-Glucopyranosyl-medicagenate (3)}

$20 \mathrm{mg}$ Glycoside 1 were dissolved in $1 \mathrm{ml}$ ethanol and treated with $20 \% \mathrm{KOH} 3 \mathrm{~h}$ under reflux. 3 could be isolated after chromatography on silicagel. M. p.: $179^{\circ} \mathrm{C}$ (decomposition). IR (KBr) $\nu_{\max } \mathrm{cm}^{-1}: 3400,2940,2620$, 2340, 1700, 1460, 1380, 1365, 1260, 1235, 1160, 1070. ${ }^{1} \mathrm{H}$ NMR (pyridine- $\left.\mathrm{D}_{5}\right): \delta 5.46(1 \mathrm{H}, \mathrm{m}), 4.47(1 \mathrm{H}, \mathrm{d}, J=$ $12 \mathrm{~Hz}$ ), 4.29 ( $1 \mathrm{H}, \mathrm{dd}, J=9$ and $3 \mathrm{~Hz}), 3.94$ (2H, bs), 3.59 $(1 \mathrm{H}, \mathrm{s}), 3.27(1 \mathrm{H}, J=15 \mathrm{~Hz}), 2.29(1 \mathrm{H}, \mathrm{d}, J=15 \mathrm{~Hz})$, $1.97,1.51,1.26,1.02,0.98,0.92$ (each $3 \mathrm{H}, \mathrm{s}) .{ }^{13} \mathrm{C}$ NMR (pyridine- $\mathrm{D}_{5}$ ): see Tables I and II.

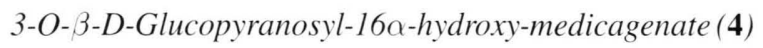

$20 \mathrm{mg}$ Glycoside 2 were dissolved in $1 \mathrm{ml}$ ethanol and treated with $20 \% \mathrm{KOH} 3 \mathrm{~h}$ under reflux. 4 could be isolated after chromatography on silicagel. M. p.: 188 $190^{\circ} \mathrm{C}$ (decomposition). IR (KBr) $\nu_{\max } \mathrm{cm}^{-1}: 3400,2950$, 2640, 1690, 1455, 1380, 1365, 1075. ' H NMR (pyridine$\left.\mathrm{D}_{5}\right): \delta 5.63(1 \mathrm{H}, \mathrm{m}), 1.98,1.81,1.57,1.70,1.07,1.02$ (each $3 \mathrm{H}, \mathrm{s}$ ). ${ }^{13} \mathrm{C}$ NMR (pyridine-D 5 ): see Tables I and II.

\section{Acknowledgements}

We are grateful to Prof. Dr. G. G. Habermehl, Hannover, and Dr. J. Döbereiner, Rio de Janeiro, for their kind support of this work and for the plant material.
[1] C. H. Tokarnia, J. Döbereiner, C. F. C. Canella, Pesq. Agropec. bras., Ser. Vet. 11, 73 (1976).

[2] L. Busam, Ph. D. Thesis University Hannover (1985).

[3] G. G. Habermehl, Toxicon 32, 143 (1994).

[4] G. Massiot, C. Lavaud, L. Le Men-Olivier, G. Van Binst, S. P. F. Miller, H. M. Fales, J. Chem. Soc. Perkin Trans I 1988, 3071.

[5] G. Klein, J. Jurenitsch, W. Kubelka, Sci. Pharm. 50, 216 (1982).

[6] P. K. Agarwal, D. C. Jenkins, R. K. Gupta, R. S. Thakur, Phytochemistry 24, 2479 (1985).
[7] R. E. Jannson, L. Kame, H. Liedgren, B. Lindberg, J. Lonngren, Chem. Commun. 8, 1 (1976).

[8] S. Hakomori, J. Biochem. 55, 205 (1964).

[9] J. H. Bradbury, G. A. Jenkins, Carbohydr. Res. 126, 125 (1984).

[10] S. Seo, Y. Tomita, K. Tori, Y. Yoshimura, J. Am. Chem. Soc. 100, 3331 (1978).

[11] K. Tori, S. Seo, Y. Yoshimura, H. Arita, Y. Tomita, Tetrahedron Lett. 12, 179 (1977).

[12] K. Bock, H. Thorgensen, Ann. Rep. on NMR spectroscopy 13, 1 (1982).

[13] P. A. J. Gorin, M. Mazurek, Can. J. Chem. 53, 1212 (1975). 